IRA-International Journal of Applied Sciences ISSN 2455-4499; Vol.07, Issue 02 (2017)

Institute of Research Advances

Pg. no. 69-74

http://research-advances.org/index.php/IRAJAS

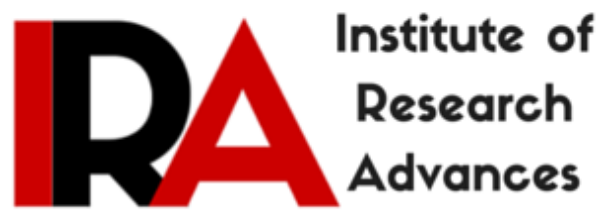

\title{
Synthesis, Characterization and Biological Evaluation of New Series of Schiff Bases Derived from Hexamethylenediamine as Potential Antibacterial and Antifungal Agents
}

KANGAH Niameke Jean-Baptiste ${ }^{1}$, KODJO Charles Guillaume ${ }^{1,2}$, OUATTARA Zana Adama ${ }^{2}$, KABLAN Ahmont Landry Claude ${ }^{3}$, DIBI Konan Jacques ${ }^{4}$, KOUAME Bosson Antoine ${ }^{2}$ and Ziao Nahosse ${ }^{1}$

${ }^{1}$ Laboratoire de Thermodynamique et Physicochimie du Milieu, Université Nangui Abrogoua, UFR-SFA, 02 B.P. 801 Abidjan 02, Côte d'Ivoire, West Africa.

${ }^{2 \#}$ Laboratoire de Chimie BioOrganique et de Substances Naturelles, Université Nangui Abrogoua, UFR-SFA, 02 B.P. 801 Abidjan 02, Côte d'Ivoire, West Africa.

${ }^{3}$ UFR des Sciences Biologiques, Université Péléforo Gon Coulibaly de Korhogo, BP 1328 Korhogo, Côte d'Ivoire, West Africa.

${ }^{4}$ Laboratoire de Chimie Organique Structurale et de Substances Naturelles, UFR SSMT, Université Félix-Houphouët Boigny, B.P 582 Abidjan 22, Côte-d'Ivoire, West Africa.

\#Corresponding author.

Type of Review: Peer Reviewed.

DOI: http://dx.doi.org/10.21013/jas.v7.n2.p3

How to cite this paper:

Jean-Baptiste, K., Guillaume, K., Adama, O., Claude, K., Jacques, D., Antoine, K., \&

Nahosse, Z. (2017). Synthesis, Characterization and Biological Evaluation of New Series of

Schiff Bases Derived from Hexamethylenediamine as Potential Antibacterial and Antifungal

Agents. IRA-International Journal of Applied Sciences (ISSN 2455-4499), 7(2), 69-74.

doi:http://dx.doi.org/10.21013/jas.v7.n2.p3

(C) Institute of Research Advances

(cc) EY-NC

This work is licensed under a Creative Commons Attribution-Non Commercial 4.0 International License subject to proper citation to the publication source of the work.

Disclaimer: The scholarly papers as reviewed and published by the Institute of Research Advances (IRA) are the views and opinions of their respective authors and are not the views or opinions of the IRA. The IRA disclaims of any harm or loss caused due to the published content to any party. 
We report herein synthesis, characterization and antimicrobial activity of four Shiff bases derived from hexamethylenediamine. Substitution of a nitro group on each aromatic ring in ortho, meta or para positions of $N, N$ '-bis(phenylmethyl)hexane-1,6-diimineallowed to have a homogeneous series of positional isomers. These four symmetric diimine Schiff bases were characterized by conventional spectrometry methods (NMR, IR, MS), then tested against Gram-positive and Gram-negative bacterial strains. Among them, compounds $\mathbf{1 b}, \mathbf{1 c}, \mathbf{1 d}$ were found to be active against bacterial strain Staphylococcus aureus CIP with MIC value of $375 \mu \mathrm{g} / \mathrm{ml}, 187.5 \mu \mathrm{g} / \mathrm{ml}$ and $375 \mu \mathrm{g} / \mathrm{ml}$ respectively. Candida Albicans fungal strain showed resistance to all synthesized Schiff base compounds, butin the other hand, Candida glabrata has been sensitive to all compounds with MIC of 1500 $\mu \mathrm{g} / \mathrm{ml}$ and one more time except 1 a.

Keywords: Schiff base, hexamethylenediamine, spectrometry, antimicrobial activity.

\section{Introduction}

Bacterial infections remain the most harmful to human health [1-2]. So, there is an urgent need for the development of new chemical entities more efficient than those currently available on the market and at the same time solving the problem of multi-drug resistance[3-4].Schiff bases, condensation products of primary amines with carbonyl compounds are considered as a very important class of organic compounds first reported by Hugo Schiff in 1864[5-6]. The common structural feature of these compounds is the azomethine group. Imine groups present in many natural compounds has been shown to be critical to their biological activities[7-8]. Our systematic research on Schiff bases in general and diimines in particular allowed us to synthesize many compounds among which the series of compounds which is the subject of this study. From $N, N^{\prime}$-bis (phenylmethylene)hexane-1,6diamine, substitution of a nitro group on each aromatic ring and its systematic displacement in the positions ortho, meta and para led to have a homogeneous series of position isomers. Versatility of Schiff base ligands and important industrial applications of their complexes explain the numerous investigations carried out on these compounds. As part of our investigations on Schiff bases, we are interested in their biological activities. Indeed, Schiff bases have showed remarkable antiviral [9], antimicrobial [10], antifungal [11], antitumors [12], anticancer [13-14] and antibacterial activities [1517].

The present paper deals with the synthesis, characterization and antimicrobial studies of all of the synthesized compounds shown in Figure1.

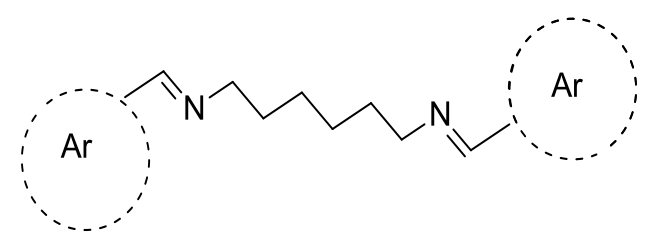

Molecule code Ar

1a

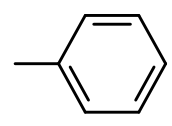

$1 b$

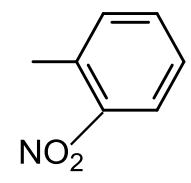




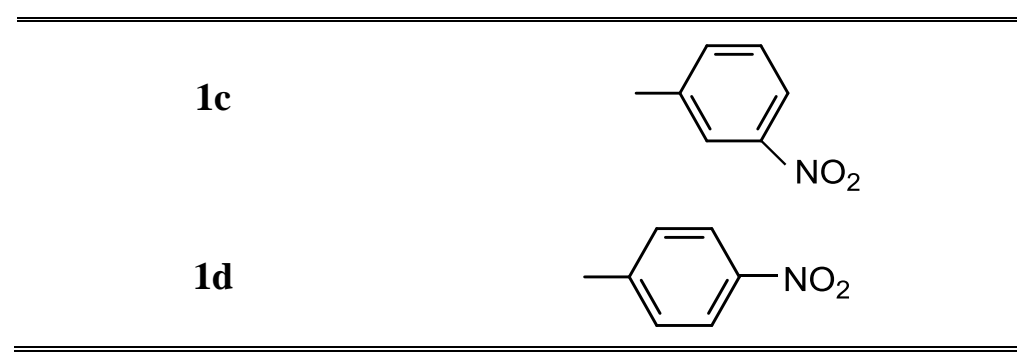

Figure 1: structures of Schiff bases synthesized

\section{Chemistry}

Synthesis of title compounds was accomplished as outlined in figure $\mathbf{2}$

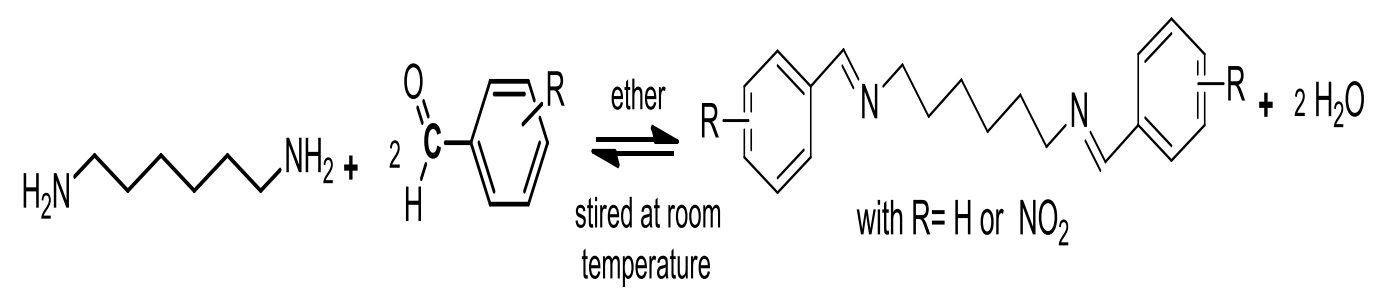

Figure 2. Way of general synthesis of compounds 1a-d

\section{Experimental protocols}

All of the chemicals used in the syntheses were purchased from Sigma-Aldrich and were used as such. Thin layer chromatography was used to monitor the progress of the reactions. Melting points were determined in capillary tube using an MPD Mitamura Riken Kogyo (Japan) electrothermal melting point apparatus and are uncorrected. IR spectra in the range $4000-400 \mathrm{~cm}^{-1}$ were obtained on a Bruker-Vector FTIR spectrophotometer, with samples investigated as thin film from $\mathrm{CDCl} 3$ solution. ${ }^{1} \mathrm{H}$ NMR spectra were recorded on a Bruker-Avance-300 spectrometer, operating at $300 \mathrm{MHz}$. Mass spectra were recorded on a TOF LCT Premier (WATERS) Spectrometer coupled to an HPLC Alliance 2695 chain.

\section{Synthesis and characterization of the compounds}

\subsection{Synthesis and characterization of $N, N^{\prime}$-bis(phenylmethylene)hexane-1,6-diamine}

Benzaldehyde $(0.4 \mathrm{mmol})$ and hexane-1,6-diamine $(0.2 \mathrm{mmol})$ were dissolved in ether $(30 \mathrm{ml})$. At room temperature, the mixture was stirred for three days to give a white milky precipitate. The precipitate obtained was filtered and recrystallized in ethanol Rf: 0.57 in hexane/acetone $(50 ; 50)$, yield: $61 \%$, mp: $198,6^{\circ} \mathrm{C}$; IR (Thin film from $\mathrm{CDCl} 3$ solution, $\left.\mathrm{cm}^{-1}\right) 2936 ; 2856 ; 1638 ;{ }^{1} \mathrm{H}$ NMR $(300$ $\mathrm{MHz}, \mathrm{CDCl} 3)$ : 8.19(s, 2H), 7.32-7.65(m, 10H), 1.35-3.51(m, 12H); ${ }^{13} \mathrm{C}$ NMR (75 MHz, CDCl3): $160.86,136.31,134.46,130.47,128.55,128.03,61.87,30.83,27.15$; ESI-HR-MS: peak at $\mathrm{m} / \mathrm{z}$ 293.2095[M+H]+ corresponding to $\mathrm{C}_{20} \mathrm{H}_{24} \mathrm{~N}_{2}$.

\subsection{Synthesis and characterization of $N, N^{\prime}$-bis(2-nitrophenylmethylene)hexane-1,6-diamine}

2-nitrobenzaldehyde $(0.4 \mathrm{mmol})$ and hexane-1,6-diamine $(0.2 \mathrm{mmol})$ were dissolved in ether $(30 \mathrm{ml})$. At room temperature, the mixture was stirred for six days to give a light brown precipitate. The precipitate obtained was filtered and recrystallized in methanol Rf: 0.82 in hexane/acetone/acetate diethyl (20; 50; 30),yield: $98.19 \%$, mp:65.6 $6^{\circ} \mathrm{C}$; IR (Thin film from $\mathrm{CDCl} 3$ solution, $\mathrm{cm}^{1}$ ) $2926 ; 2860$ ; 1633; 1522; ${ }^{1} \mathrm{H}$ NMR (300 MHz, MeOD):8.56(s, 2H),7.75-8.10(m, 8H),1.38-3.61(m, $\left.12 \mathrm{H}\right) ;{ }^{13} \mathrm{C}$ NMR (75 MHz, MeOD): 154.10,146.29,127.94 , 127.15 , 128.81, 130.87 ,131.49,59.05, 28.01,24.46; ESI-HR-MS: peak at $m / z 383.1726[\mathrm{M}+\mathrm{H}]^{+}$corresponding to $\mathrm{C}_{20} \mathrm{H}_{22} \mathrm{~N}_{4} \mathrm{O}_{4}$. 


\subsection{Synthesis and characterization of $N, N^{\prime}$-bis(3-nitrophenylmethylene)hexane-1,6-diamine}

3-nitrobenzaldehyde $(0.4 \mathrm{mmol})$ and hexane-1,6-diamine $(0.2 \mathrm{mmol})$ were dissolved in ether $(30 \mathrm{ml})$. At room temperature, the mixture was stirred for four days to give a pale yelow precipitate. The precipitate obtained was filtered and recrystallized in methanol Rf: 0.88 in hexane/acetone (50;50),yield: $98 \%, \mathrm{mp} 82.6^{\circ} \mathrm{C}$; IR (Thin film from $\mathrm{CDCl} 3$ solution, $\mathrm{cm}^{-1}$ ): 2944, 2859, 1648,$1522 ;{ }^{1} \mathrm{H}$ NMR (300 MHz, CDCl3): $8.50(\mathrm{~s}, 2 \mathrm{H}), 7.51-8.33(\mathrm{~m}, 8 \mathrm{H}), 1.41-3.61(\mathrm{~m}, 12 \mathrm{H}) ;{ }^{13} \mathrm{C}$ NMR (75 MHz, CDCl3): 158.67,148.46,138.38,134.05,129.06, 124.74, 122.52, 61.48, 30.63, 27.10;ESI-HR-MS: peak at $m / z 383.1731[\mathrm{M}+\mathrm{H}]^{+}$corresponding to $\mathrm{C}_{20} \mathrm{H}_{22} \mathrm{~N}_{4} \mathrm{O}_{4}$.

\subsection{Synthesis and characterization of $N, N^{\prime}$-bis(4-nitrophenylmethylene)hexane-1,6-diamine}

4-nitrobenzaldehyde $(0.8 \mathrm{mmol})$ and hexane-1,6-diamine $(0.4 \mathrm{mmol})$ were dissolved in ether $(30 \mathrm{ml})$. At room temperature, the mixture was stirred for three days to give a white precipitate. The precipitate obtained was filtered and recrystallized in methanolRf: 0.81 in hexane/acetone $(50 ; 50)$, yield: 86,26 $\%$, mp 132, $6^{\circ} \mathrm{C} ; \mathrm{IR}$ (Thin film from $\mathrm{CDCl} 3$ solution, $\mathrm{cm}^{-1}$ ): $2853 ; 2819 ; 1643 ; 1535 ; 850 ;{ }^{1} \mathrm{H}$ NMR (300 MHz, MeOD): 8.50 (s, 2H),7.98-8.30(m, 8H),1.39-3.64(m, 12H); ${ }^{13} \mathrm{C}$ NMR (75 MHz, MeOD): 155.92,146.44,139.27,126.14, 129.06, 121.33,59.33, 28.12,24.65;ESI-HR-MS: peak at $\mathrm{m} / \mathrm{z} 383.1741$ $[\mathrm{M}+\mathrm{H}]^{+}$corresponding to $\mathrm{C}_{20} \mathrm{H}_{22} \mathrm{~N}_{4} \mathrm{O}_{4}$.

\section{Biological activity}

\subsection{Antibacterial testing}

The bacterial cultures: Staphylococcus aureus ATCC 25923, Staphylococcus aureus (CIP) 4.83, Pseudomonas aeruginosa (CIP) 103467, E. coli (CIP) 54127AFandStaphylococcus aureus sensitive to penicillinwere obtained from Pasteur Institute Collection (CIP) of Abidjan (Cote D'Ivoire) and also provided by the National Laboratory of Public Health of Abidjan (Cote D'Ivoire). The bacterial cultures were incubated at $37^{\circ} \mathrm{C}$ for 18 hours by inoculation into nutrient agar. Schiff bases were stored dry at room temperature and dissolved $1500 \mu \mathrm{g} / \mathrm{mL}$ then $250 \mu \mathrm{g} / \mathrm{ml}$ in dimethylsulfoxide (DMSO). Antibacterial activities of each compound were evaluated by the agar disc-diffusion method. Mueller Hinton Agar Media $\left(15 \mathrm{~cm}^{3}\right)$ kept at $45^{\circ} \mathrm{C}$ was poured in the Petridishes and allowed to solidify. Poured Petri plates $(9 \mathrm{~cm}$ ) were incubated with $50 \mu \mathrm{L}$ of normal saline solution of above culture media $\left(10^{5}-10^{6}\right.$ bacteria per $\left.\mathrm{ml}\right)$. Discs injected with prepared Schiff bases $(50 \mu \mathrm{l})$ were applied on the solid agar medium by pressing tightly. The Petri plates were placed at $37^{\circ} \mathrm{C}$ for 18 hours. At the end of period the inhibition zones formed on media were measured with a zone reader in millimeters.

\subsection{Antifungal testing}

Pathogenic strains of Candida albicans and Candida glabatawere obtained from National Laboratory of Public Health of Cote D'Ivoire and the Microbiology Laboratory of Swiss Scientific Research Center in Cote D'Ivoire. Schiff bases were stored dry at room temperature and dissolved $1500 \mu \mathrm{g} / \mathrm{ml}$ in dimethylsulfoxide (DMSO). Antifungal activities of each compound were evaluated by the agar disc-diffusion method. Sabarod's agar media $\left(15 \mathrm{~cm}^{3}\right) \mathrm{kept}$ at $45^{\circ} \mathrm{C}$ was poured in the Petri-dishes and allowed to solidify. Sterile, filter paper discs of $10 \mathrm{~mm}$ diameter were impregnated with prepared Schiff bases $(50 \mu 1)$ and were placed on to the media, seeded with fungus. The plates were then incubated at $37^{\circ} \mathrm{C}$ for 1-3 days. At the end of period the inhibition zones formed on media were measured with a zone reader in millimeters.

\section{Results and Discussion}

Four symmetric Schiff bases have been synthesized from the condensation reaction of 1,6diaminohexane with benzaldehyde, and ortho, meta or para $\mathrm{NO}_{2}$-substituted benzaldehyde.The results of the antibacterial screening of compounds1b, 1c, and1d at a concentration of $1500 \mu \mathrm{g} / \mathrm{ml}$ against Staphylococcus aureus (CIP) 4.83 and Staphylococcus aureus sensitive to penicillinhave been found. The inhibition zones were measured in $\mathrm{mm}$ and results are shown in Table 1.The inhibition zones diameters were between 10 and $16 \mathrm{~mm}$. The results indicated that, this compounds showed significant activity against Staphylococcus aureus(CIP) 4.83 than Staphylococcus aureus sensitive to penicillin, while they were found to be inactive against Escherichia coli(CIP) 54127AF, Pseudomonas aeruginosa (CIP) 103467,Staphylococcus aureus ATTC 25923. Antibacterial activity of these 
compounds showed ascending order. When we increased concentration, area of inhibited growth also increased. We noted that compound 1a without nitro group was inactive on all the strains. On the strain Staphylococcus aureus(CIP), the compound 1cwas the most active with a MIC of $187.5 \mu \mathrm{g} / \mathrm{ml}$, and the compounds $\mathbf{1 b}$ and 1dthe least active with a MIC of $375 \mu \mathrm{g} / \mathrm{ml}$, whereas on the strain Staphylococcus aureus sensible, only compound1c has activity with a MIC value greater than $1500 \mu \mathrm{g} / \mathrm{ml}$.

TABLE 1: Measurement of inhibition diameters and value of minimum inhibition concentration (MIC) for antibacterial activity

\begin{tabular}{|c|c|c|c|c|c|c|c|c|c|c|c|c|}
\hline \multirow{3}{*}{ Strains tested } & \multicolumn{10}{|c|}{ Measurement of inhibition diameters (mm) } & \multicolumn{2}{|c|}{ Value of MIC $(\mu \mathrm{g} / \mathrm{ml})$} \\
\hline & \multicolumn{2}{|c|}{$\begin{array}{l}\text { Pseu a } \\
\text { CIP }\end{array}$} & \multicolumn{2}{|c|}{$\begin{array}{l}\text { Sta } a \\
\text { CIP }\end{array}$} & \multicolumn{2}{|c|}{$\begin{array}{l}\text { Sta a } \\
\text { sens }\end{array}$} & \multicolumn{2}{|c|}{$\begin{array}{l}\text { E. coli } \\
\text { CIP }\end{array}$} & \multicolumn{2}{|c|}{$\begin{array}{l}\text { Sta } a \\
\text { ATTC }\end{array}$} & \multirow{2}{*}{ Sta a CIP } & \multirow{2}{*}{ Sta a sens } \\
\hline & \multicolumn{10}{|c|}{$\begin{array}{c}\text { Concentrations }(\mu \mathrm{g} / \mathrm{ml}) \\
\mathrm{C} 1=1500: \mathrm{C} 2=250: \mathrm{C} 3=25\end{array}$} & & \\
\hline Compounds & $\mathrm{C} 1$ & $\mathrm{C} 2$ & $\mathrm{C} 1$ & $\mathrm{C} 2$ & $\mathrm{C} 1$ & $\mathrm{C} 2$ & $\mathrm{C} 1$ & $\mathrm{C} 2$ & $\mathrm{C} 1$ & $\mathrm{C} 2$ & $\begin{array}{l}\text { MIC } \\
(\mu \mathrm{g} / \mathrm{ml})\end{array}$ & $\begin{array}{l}\text { MIC } \\
(\mu \mathrm{g} / \mathrm{ml})\end{array}$ \\
\hline $\mathbf{1 a}$ & 0 & 0 & 0 & 0 & 0 & 0 & 0 & 0 & 0 & 0 & - & - \\
\hline $\mathbf{1 b}$ & 0 & 0 & 13 & 10 & 0 & 0 & 0 & 0 & 0 & 0 & 375 & - \\
\hline 1c & 0 & 0 & 16 & 10 & 11 & 0 & 0 & 0 & 0 & 0 & 187.5 & $>1500$ \\
\hline $1 d$ & 0 & 0 & 16 & 10 & 0 & 0 & 0 & 0 & 0 & 0 & 375 & - \\
\hline Witnesses & $\mathrm{C} 3$ & C3 & C3 & C3 & $\mathrm{C} 3$ & C3 & C3 & C3 & $\mathrm{C} 3$ & C3 & & \\
\hline Gen & 23 & 10 & 29 & 23 & 32 & 23 & 12 & 0 & 19 & 10 & 0.78 & 12.5 \\
\hline Tetra & 0 & 0 & 36 & 29 & 27 & 19 & 29 & 17 & 24 & 15 & 0.0976 & 12.5 \\
\hline
\end{tabular}

Values are averages of three repetitions; Gen: Gentamicin; Tetra: Tetracycline;Sta a sens: Staphylococcus aureus sensitive to penicillin;Sta a:Staphylococcus aureus;Pseu a :Pseudomonas aeruginosa $; \boldsymbol{E}$. coli : Escherichia coli

All synthesized compounds show no antifungal activity even at $1500 \mu \mathrm{g} / \mathrm{ml}$ against $C$. albicans, as shown in Table 2.However, on C.glabrata, all compounds showed activities with inhibition diameters between 10 and $11 \mathrm{~mm}$. Compound 1a has a minimum inhibition concentration greater than $1500 \mu \mathrm{g} / \mathrm{ml}$, on the other hand for compounds $\mathbf{1 b}, \mathbf{1 c}, 1$ dthe MIC value was $1500 \mu \mathrm{g} / \mathrm{ml}$.

TABLE2: Measurement of inhibition diameters and value of minimum inhibition concentration (MIC) for antifungal activity

\begin{tabular}{|l|l|l|l|l||}
\hline & \multicolumn{2}{|l|}{$\begin{array}{l}\text { Mean diameters of the } \\
\text { inhibition zones }(\mathrm{mm})\end{array}$} & Value of MIC $(\mu \mathrm{g} / \mathrm{ml})$ & Value of MIC $(\mu \mathrm{g} / \mathrm{ml})$ \\
\hline Strains tested & C.albicans & C.glabrata & C.albicans & C.glabrata \\
\hline \multirow{3}{*}{ Compounds } & Concentrations & MIC \\
\cline { 2 - 5 } & $\mathrm{C} 1=1500 \mu \mathrm{g} / \mathrm{ml} / \mathrm{ml})$ & $\begin{array}{l}\mathrm{MIC} \\
(\mu \mathrm{g} / \mathrm{ml})\end{array}$ \\
\hline \hline 1a & 0 & 10 & - & $>1500$ \\
\hline 1b & 0 & 10 & - & 1500 \\
\hline 1c & 0 & 10 & - & 1500 \\
\hline 1d & 0 & 11 & - & 1500 \\
\hline Témoins & 0 & $\mathrm{C} 3=25 \mu \mathrm{g} / \mathrm{ml}$ & - & \\
\hline Ampho B & 0 & 0 & 50 & - \\
\hline Nyst & 11 & 0 & & - \\
\hline
\end{tabular}




\section{Conclusion}

Schiff bases compounds 1a-d were synthesized and characterized by spectral techniques. For antibacterial activities, compound 1a without nitro groups was inactive on all the strains tested. On the other hand compounds $\mathbf{1 b}, \mathbf{1 c}, \mathbf{1 d}$ with nitro groups have shown activities on the bacterial strains Staphylococcus aureus (CIP) 4.83 and Staphylococcus aureus sensitive to penicillin. However, it is noted that meta position of the nitro group was the most active with a minimum inhibition concentration of $187.5 \mu \mathrm{g} / \mathrm{ml}$. Concerning antifungal activities, no compound has positive result at the concentration tested with $C$. albicans. But, on C. glabrata, one more time, only nitro-substituted compounds $(\mathbf{1 b}, \mathbf{1 c}, \mathbf{1 d})$ showed activity with minimal inhibition concentrations of $1500 \mu \mathrm{g} / \mathrm{ml}$. The presence of the nitro group on the various benzene rings seems to be decisive for the manifestation of an important activity of these compounds.

\section{References}

[1] K.E. Jones, N.G. Patel, M.A. Levy, A. Storeygard, D. Balk, J.L. Gittleman,P. Daszak, Nature ,451 , 2008, 990-993.

[2] D.M. Morens, G.K. Folkers, A.S. Fauci, Nature, 430, 2004, 242-249.

[3] H. Lode, Clin. Microbiol. Infect. 11, 2005, 778-787.

[4] L.B. Rice, Biochem. Pharmacol. 71, 2006, 991-995.

[5] H.Schiff,Ann Chem. Paris. 131 (1864)118-119.

[6] S. Arulmurugan, P.H. Kavitha, R. P. Venkatraman, Rasayan J Chem. 3(3) , 2010, 385-410.

[7] J. Salimon, N. Salih, H. Ibraheem, E. Yousif, Asian J Chem. 22(7), 2010, 5289-5296.

[8] G.Bringmann, M.Dreyer,J.H. Faber,P.W. Dalsgaard, D.Staerk, J.W.Jaroszewski,. J Nat Prod. 67(5), 2004, 743-748.

[9] K.S. Kumar, S. Ganguly, R. Veerasamy, E. De Clercq, Eur. J. Med. Chem. 45, 2010, 5474.

[10] C.M. da Silva, D.L. da Silva, L.V. Modolo, R.B. Alves, M.a. de Resende, C.V.B. Martins, A. de Fatima, J. Adv. Res. 2, 2011, 1.

[11] O. Gungor, P. Gurkan, J. Mol. Struct. 1074, 2014, 62.

[12] S. Amer, N. El-Wakiel, H. El-Ghamry, J. Mol. Struct. 1049,2013,326.

[13] S.M. Bensaber, H.a. Allafe, N.B. Ermeli, S.B. Mohamed, A.a. Zetrini, S.G. Alsabri,M. Erhuma, A. Hermann, M.I. Jaeda, A.M. Gbaj, Med. Chem. 23, 2014, 5120.

[14] A. Sinha, K. Banerjee, A. Banerjee, S. Das, S.K. Choudhuri, J. Organomet. Chem.34, 2014, 772.

[15] A.K. Singh, S.K. Pandey, O.P. Pandey, S.K. Sengupta, J. Mol. Struct. 1074, 2014, 376.

[16] H.A.R. Pramanik, D. Das, P.C. Paul, P. Mondal, C.R. Bhattacharjee, J. Mol. Struct.1059, 2014, 309.

[17] C.M. da Silva, D. da Silva, L.V. Modolo, R.B. Alves, M.A. de Resende, C.V.B.Martins, A. de Fatima, J. Adv. Res. 2, 2011, 1. 